\title{
iN

\section{Tüketicilerin Online Karar Verme Tarzlarının Sosyo-Demografik Özellikleri Bakımından İncelenmesi}

\section{The research of consumers' online decision-making styles in terms of socio- demographic characteristics}

\author{
Tülay YENIÇERİ ${ }^{1}$, tyeniceri@bandirma.edu.tr \\ Özlem ŞENEL 2, ozlemsenel@aydin.edu.tr
}

Received: 09.07.2020; Accepted: 01.05.2021

One way of understanding consumer behavior, which is one of the cornerstones of marketing, is to learn how consumers decide to purchase. Over the years, the increase in the rate at which individuals turn to online shopping makes it necessary to understand how purchasing decision styles occur online and to study this issue in depth. Based on this development, the main purpose of the study is to investigate the online decision-making styles of consumers in terms of socio-demographic characteristics such as gender, marital status, age, education level, occupation, monthly family income and to determine whether there is a significant difference. For this purpose, data were collected from 341 participants using the online questionnaire method. Hypotheses were tested using independent sample T-test and one-way analysis of variance (ANOVA) from parametric tests with higher statistical power due to the normal distribution of the data. According to the results of the analysis, it was determined that the online purchasing decision styles of consumers at the 5\% significance level have a significant difference according to gender, marital status, age, occupation, monthly family income level, but not according to the education level.

Keywords: Online Shopping, Consumer Decision Making Styles, Socio-Demographic Characteristics
Pazarlamanın temel taşlarından olan tüketici davranışların anlamanın bir yolu tüketicilerin ne şekilde satın alma kararı verdiklerini öğrenebilmektir. Yillar geçtikçe bireylerin online alışverişe yönelme oranının artması ise satın alma karar tarzlarının çevrimiçi ortamda nasıl gerçekleştiğini anlamayı ve bu konunun derinlemesine incelenmesini gerekli kılmaktadır. Bu gelişmeden yola çıkarak tüketicilerin online karar verme tarzlarm cinsiyet, medeni durum, yas, eğitim düzeyi, meslek, aylık aile geliri gibi sosyo-demografik özellikler açısından araştırmak ve aralarında anlamlı bir farklılık olup olmadığını tespit etmek çalışmanın ana amacını oluşturmaktadır. Bu amaç doğrultusunda online anket yöntemiyle 341 katılımcıdan veriler toplanmıştır. Verilerin normal dağılım göstermesinden dolayı istatistiksel gücü daha yüksek olan parametrik testlerden bağımsız örneklem $T$ testi ve tek yönlü varyans analizi (ANOVA) kullanılarak hipotezler test edilmiştir. Analizlerin sonucuna göre \%5 anlamlllk düzeyinde tüketicilerin online satın alma karar tarzları cinsiyet, medeni durum, yaş, meslek, aylık aile gelir düzeyine göre anlamlı bir farklılı̆̆a sahipken eğitim düzeyine göre anlamlı bir farklılı̆̆ın olmadı̆̆ı tespit edilmiştir.

Anahtar Kelimeler: Online Alı̧̧veriş, Tüketici Karar Verme Tarzları, Sosyo-Demografik Özellikler

\footnotetext{
${ }^{1}$ Bandırma Onyedi Eylül Üniversitesi İktisadi ve İdari Bilimler Fakültesi, Öğretim Üyesi

2 İstanbul Aydın Üniversitesi Anadolu Bil MYO, Öğretim Görevlisi (Sorumlu Yazar)
} 


\section{GİRIŞ}

İnternetin yaygınlaşmasıyla beraber tüketicilerin istedikleri zamanda ve mekanda bilgisayar ve tabletler dışında telefonlarından dahi çeşitli alışveriş sitelerine ve uygulamalarına rahatlıkla girerek alışveriş kolaylığını yaşamaları online alışverişi cazip hale getiren temel gelişmelerden biri olmuştur.

Çevrimiçi ortamda alışverişin güvenilirliği konusunda endişeleri ve korkuları devam eden bir kesim olsa da tüm dünyada olduğu gibi Türkiye'de de online alışverişin tercih edilme oranı yıllar geçtikçe artış göstererek devam etmektedir. 2019 yılı Türkiye İstatistik Kurumu (TÜİK) "Hanehalkı Bilişim Teknolojileri Kullanım Araştırmasına" göre İnternet üzerinden kişisel kullanım amacıyla mal veya hizmet siparişi veren ya da satın alan 16-74 yaş grubundaki bireylerin oranı \%75.3 olup cinsiyete göre ise İnternet üzerinden alışveriş yapma oranı erkeklerde \%81.8, kadınlarda \%68.9 iken 2020 yılına ait verilerde İnternet üzerinden kişisel kullanım amaciyla mal veya hizmet siparişi veren ya da satın alan 16-74 yaş grubundaki bireylerin oranı \%79 olup bu oran erkeklerde \%84.7, kadınlarda ise \%73.3 olarak belirtilmiştir. Dolayısıyla her geçen yıl online alışveriş oranı artmakta ve bu oran içerisinde erkekler kadınlardan daha fazla online alışveriş yapmaktadır.

Aynı ürün kategorisi dahi olsa, tüketicilerin mağaza ya da internet ortamında aldıkları kararlar değişiklik gösterebilmektedir (Bayrakdaroğlu ve Çakır, 2016). Bu nedenle geleneksel alışveriş ve online alışveriş yapma tercihinde bulunan tüketicilerin satın alma karar tarzlarında farklılıklar olabileceği düşünülerek satın alma karar tarzlarının online alışveriş çerçevesinde ele alınması çalışmanın ana temasını oluşturmaktadır.

Günümüz tüketicilerinin çok fazla seçeneğe sahip olmaları karar vermelerini zorlaştırmakta ve satın alma sonrası pişmanlık yaşamamak adına kararlarını kendilerine göre bazı makul nedenlere dayalı olarak vermeye itmektedir. Kimi tüketici için fiyat, kimi için kalite, kimi için ise modaya uygunluk temel karar belirleyicisi olabilmektedir. Çevrimiçi alışveriş söz konusu olduğunda ise bireylerin alışveriş yaptığı web sitelerinin içerikleri, arayüzleri ya da uygulamaları dahi satın alma kararlarında etkili olabilmektedir. Alışveriş sitesinin yavaş açılması, güvenilir online ödeme sistemi olmaması, sipariş sisteminin etkin olmaması gibi sebepler dolayısıyla tüketiciler ilgili alışveriş sitesini terk ederek satın almaktan kolayca vazgeçebilmektedir. Ancak bu etkenler üzerinde bireylerin sosyo-demografik özelliklerinin de etkisi olduğu gerçeği göz ardı edilemeyecektir. Bu nedenle çalışmada ülkemizde İnternetten alışveriş yapan tüketicilerin online karar verme tarzlarının cinsiyet, medeni durum, yaş, eğitim düzeyi, meslek, aylık aile geliri gibi sosyo-demografik özelliklere göre farklılaşıp farklılaşmadığının Sam ve Chatwin (2015) tarafından geliştirilmiş, Bayraktaroğlu, Taşçıŏlu ve Özkoç (2017) tarafından Türkçe'ye uyarlanan yedi boyut çerçevesinde incelenmesi amaçlanmıştır. Çalışmanın literatüre sağlayacağı katkının yanında elde edilen bulguların pazarlama yöneticilerine özellikle de segmentasyon çalışmalarında rehberlik edeceği düşünülmektedir.

\section{TEORIKK VE KAVRAMSAL ÇERÇEVE}

\subsection{Tüketici Karar Verme Tarzları}

İşletmelerin hedef pazarlarını belirleyebilmesi ve bu çerçevede stratejilerini uygulayabilmeleri bakımından, tüketici davranışlarının detaylı incelenmesi büyük önem taşımaktadır. İşletmeler 
tüketici davranışlarını doğru analiz etmek suretiyle, alacakları kararlardaki riskleri azaltabilir ve hedeflerine ulaşabilirler.

Tüketici karar verme tarzı, Sproles ve Kendall (1986) tarafından bilişsel ve duygusal özelliklere sahip seçim yapmayı sağlayan zihinsel bir yönelim olarak tanımlanmakta ve bu alanı incelemek üzere oluşturdukları mükemmeliyetçilik-yüksek kalite odaklılık, marka odaklılık, yenilik-moda odaklılık, eğlence-haz odaklılık, fiyat odaklılık, düşünmeden alışveriş etmedikkatsizlik, bilgi karmaşası yaşama, alışkanlık-marka bağlılığı odaklılık olmak üzere sekiz boyutlu ve 40 ifadeden oluşan “Tüketici Tarzları Envanteri (TTE)" konuyla ilgili öncülüğe sahiptir. Lysonski ve Durvasula (2013) ise bu sekiz temel tüketici karar verme tarzının 19942009 yılları arasındaki değişimini incelemiş ve marka duyarlılığı, moda duyarlılığı ve dürtüsel satın almanın artış gösterdiğini, kalite duyarlılığının ise azaldığını belirtmiştir.

Tüketici karar verme tarzlarını sosyo-demografik özellikler açısından incelemiş çeşitli araştırmalar da mevcut olup Mitchell ve Walsh (2004) çalışmalarında erkeklerin kaliteye ve modaya daha az duyarlı, kadınların ise marka, kalite ve modaya daha çok duyarlı olarak satın alma kararı verdiği sonucuna ulaşmıştır. Bakewell vd. (2006) ise çalışmalarında erkeklerin problem çözme veya ihtiyacın tatmini amaçlı satın alma kararı verdiklerini, kadınların bir eğlence etkinliği olarak alışveriş yaptıklarını belirtmiştir. Bae ve Miller (2009) spor giyim alışverişi konusunda üniversite öğrencilerin karar alma tarzlarını cinsiyet açısından karşılaştırmış ve fiyat ve moda duyarlılığı açısından farklılıkları olmadığı ancak kadınların daha marka duyarlı, düşünmeden satın alma, kalite odaklı, bilgi karmaşası yaşama gibi karar tarzlarına sahip olduğunu belirtmişlerdir. Potgieter vd. (2013)'in Güney Afika'da yaptığ1 çalışma sonuçlarına göre kadınların daha eğlence-haz odaklı, yenilikçi moda duyarlı ve fiyat duyarlı iken erkeklerin daha çok kalite duyarlı olduğunu, genç tüketicilerin eğlence haz odaklı alışveriş tarzına sahip olup daha moda duyarlı ve dürtüsel satın aldıklarını, düşük eğitim seviyesine sahip kişilerin daha marka duyarlı, yüksek eğitimli kişilerin ise daha az fiyat odaklı ve daha az dürtüsel satın alma yaptıkları sonuçlarına ulaşmıştır.

Ülkemizde yapılan çalışmalardan biri olan Bayrakdaroğlu ve Çakır (2016)'ın araştırmasında Dursun vd. (2013) tarafından uyarlanmış dokuz faktörlü tüketici tarzı envanterinden yararlanılmış ve mükemmeliyetçilik-yüksek kalite odaklılık, marka odaklılık, yenilik-moda odaklılık, fiyat odaklılık, düşünmeden alışveriş, alışkanlık, bilgi karmaşası yaşama, alışverişten kaçınma ve kararsızlık yaşama şeklindeki karar alma tarzlarının cinsiyete, yaşa, eğitim düzeyine, çalışma durumuna, aylık harcama düzeylerine göre farklılık göstermediği ancak medeni duruma, gelir seviyesine, yapılan alışverişin süresine ve ayrılan alışveriş bütçesine bağlı olarak farklılık gösterdiği tespit edilmiştir. Aynı zamanda bekarlar ile aylık ortalama geliri düşük olanların daha fiyat odaklı, evlilerin ise daha kararsız olduğu görülmüştür.

Yeniçeri ve Özal (2016) cinsiyet kimliği açısından tüketici karar alma tarzlarını incelediği çalışmalarında maskülen tüketicilerin daha mükemmelliyetçi-yüksek kalite odaklı, fiyat odaklı, düşünmeden alışveriş yapan, feminen tüketicilerin ise daha marka odaklı, eğlence-haz odaklı, bilgi karmaşası yaşayan kişiler olduklarını belirtmiştir.

Sundu ve Yaşar (2017)'ın çalışmalarının sonucunda tüketici karar verme tarzlarının yaş ve eğitim seviyesine göre farklılık göstermediği ancak cinsiyete göre kadınların daha fazla mükemmelliyetçi ve marka odaklı, erkeklerin ise daha fazla fiyat odaklı, düşünmeden 
alışveriş yapma, bilgi karmaşası yaşama ve sadık yönlü karar verme stiline sahip olarak farklılaştı̆̆ 1 ve gelire göre ise düşük gelirlilerin daha fiyat odaklı karar vermesi açısından farklılaştığı görülmüştür. Yücel (2017) beyaz eşya alımı üzerine yaptığı çalışmasında satın alma karar tarzlarının cinsiyete, yaşa, gelire, medeni duruma, çalışma durumuna ve haneye en çok gelir getiren kişiye göre anlamlı farklılık gösterirken eğitim düzeyine göre anlamlı fark göstermediği sonucuna varmıştır.

Özden (2019b), sosyo demografik özellikleri moda odaklılık açısından incelediği çalışmasında erkek tüketicilerin kadın tüketicilere göre; 36-45 yaş aralığındaki tüketicilerin 18-25 yaş aralığındaki tüketicilere göre; doktora, yüksek lisans ve lisans düzeyinde eğitimi olan tüketicilerin ilköğretim, lise ve önlisans eğitim düzeyinde olan tüketicilere göre ve geliri yüksek olan tüketicilerin geliri düşük olan tüketicilere göre marka odaklı karar verme tarzı gösterdiklerini tespit etmiştir.

Kuşaklar açısından yapılan çalışmalarda ise Kavalcı ve Ünal (2016) Z kuşağı tüketicilerin Y kuşağı tüketicilere göre daha fazla hedonik-eğlence odaklı oldukları, Yüksekbilgili (2016) X ve Y kuşağı tüketicilerin moda odaklılık, fiyat odaklılık, bilgi karmaşası yaşama, alışkanlıkmarka bağlılığı odaklılık boyutlarında farklılaştıkları, Özden (2019a) ise Z kuşağının daha mükemmeliyetçi, marka, moda, düşünmeden/dikkatsiz alışveriş, bilgi karmaşası ve alışverişten kaçınma odaklı, Y kuşağının ise fiyat, alışkanlık ve kararsızlık odaklı olduğu sonucuna ulaşmıştır.

Yeniçeri ve Özbezek (2019) ise konuyu ülkemize sı̆̆ınmacı olarak gelen Suriyelilerin eğitim düzeyleri açısından araştırmış ve lise düzeyinde öğrenim gören Suriyeli sığınmacıların yenilik-moda yönlülük, düşünmeden alışveriş yapma-dikkatsizlik ve eğlence-haz bilinci algılarının daha yüksek düzeyde olduğunu tespit etmiştir.

Tüketicilerin satın alma karar tarzlarını inceleyen çok sayıda çalışma mevcut olup çalışmaların yapıldığı ülkeler, katılımcıların cinsiyetleri, yaşları, eğitim düzeyleri, gelir düzeyleri vb. faktörlere göre sonuçlar değişiklik gösterebilmektedir. Bireyler günümüzde sahip oldukları birçok avantajlar nedeniyle daha çok çevrimiçi ortamlarında alışveriş yapmayı tercih etmektedir. Dolayısıyla online satın alma ortamı geleneksel kanallardakinden farklı olarak bazı yeni karar verme kriterlerini ortaya çıkarmıştır (Bayrakdaroğlu vd., 2017).

\subsection{Online Alışverişte Tüketici Kararına Etki Eden Faktörler ve Tüketim Tarzları}

İnternet kullanımının daha yaygın hale gelmesiyle beraber tüketiciler açısından düşük maliyet, zaman tasarrufu, daha bol seçenek, hızlı, kolay ve zevkli bir alışveriş sunan işletmeler açısından ise daha büyük kitlelere ulaşmayı sağlayan "online alışveriş" ortaya çıkmıştır (Adıgüzel, 2010). Gelişmiş ülkelerde olduğu gibi ülkemizde de tüketicilerin hayat tarzlarının değişmesi ve zaman kısıtı gibi faktörler, geleneksel ortamlarda alışverişe alternatif olarak online alışverişin yaygınlaşmasını sağlamaktadır (Usta, 2006).

Online alışveriş, bireylerin İnternet bağlantısı kanalıyla çeşitli web siteleri, e-ticaret siteleri, uygulamalar üzerinden mal ve hizmet satın almasıdır. Online alışveriş, coğrafi sınırları kaldırarak, daha az vakit ve nakit harcayarak daha fazla bilgiye ulaşılmasını sağlamanın yanı sıra işletmelere hem tüketicilerin beklentilerine ve taleplerine uygun mal ve hizmetlerini sunabilme hem de bunu daha az maliyetle ve daha kısa teslimat süresi ile yapabilme imkanını vermektedir (Turan, 2008). 
Bilgisayar ve İnternet teknolojilerindeki değişimler sayesinde alıcı ile satıcı fiziksel olarak bir araya gelmeden de mallar/hizmetler alınıp satılabilir hale gelmiş ve elektronik pazarlar ortaya çıkmış olup (Kalyoncuoğlu, 2018) bu pazarlar ile tüketiciler yorulmadan, mağaza ve vitrin gezmek zorunda kalmadan, hem de karşılaştırma yapıp farklı kişilere danışıp fikir alarak satın alma problemini çözebilmektedir (Enginkaya, 2006).

İnternetin insanlara daha fazla kontrole sahip olma ve satıcıları karşılaştırma olanağı sunmasından dolayı online alışveriş fiziki mağazalara göre birçok açıdan daha kolaydır. İnsanlar İnternet üzerinden gerekli bilgilere büyük bir kolaylıkla ulaşabilmekte, diğer ürün ve satıcılarla karşılaştırabilmektedir. Online alışveriş bir mağazadan diğerine gitmeye veya bir veya daha fazla mağaza içinde dolaşmaya gerek olmadan tüketicilerin tamamen bilgi edinme ve satın alma kararı vermesine konsantre olmasına izin verme, bir ürünle ilgili mevcut bilgilere ulaşım rahatlığı, daha önce deneyimlemiş kişilerin fikirlerine erişim imkanı, kıyaslama yeteneği, çok çeşitli ürünlere ve alışveriş yerlerine erişim imkanı ve hız gibi birçok faydayı tüketicilere sunabilmektedir (Alreck ve Settle, 2002; Gökçek, 2020).

Tüketicilerin hayatına hızla giriş yapan İnternet dolayısıyla birçok satın alım kararının online ortamda verilmeye başlaması ie ilgili süreç hızlanmış ve bu sonuç online alışverişin önemini akademik boyutta artırmıştır (Bayrakdaroğlu vd., 2017). Dolayısıyla hem ulusal hem de uluslararası literatürde konuya dair çok sayıda çalışmaya rastlanmaktadır.

Uluslararası yazın taraması yapıldığında konuyla ilgili olarak Li vd. (1999) çalışmalarında erkeklerin ve öğrenim düzeyi ile gelir seviyesi yüksek olanların daha sık online alışveriş tercih ettiklerini ancak yaşın anlamlı bir etkisi olmadığını tespit etmiştir. Yang ve Wu (2007) İnternetten alışveriş yapan bireylerin cinsiyete göre satın alma karar tarzlarını araştırmış ve kadınların moda odaklı, erkeklerin ise marka odaklı satın alma kararı verdikleri sonucuna ulaşmıştır. Naseri ve Elliott (2011) ise çalışmalarında benzer sonuçlara ulaşmış ve erkeklerin, yüksek eğitimli, gelir seviyesi yüksek kişiler ile evli/çift olanların online alışverişi benimseme olasıklarının daha yüksek olduğu sonucuna ulaşmıştır. Kalia (2016) erkek, iyi eğitimli, genç, profesyonel, ortalama üzeri gelir sahibi kişilerin daha çok online alışveriş yaptığını, medeni durumun ise online alışveriş üzerinde bir etkisi olmadığını belirtmiştir. Oskaybaş vd. (2015) çalışmalarında gençlerin, eğitim düzeyi yüksek olanların ve çocuk sahibi olmayan tüketicilerin daha çok online satın alımlar yaptığını tespit etmiştir. Sharma ve Jain (2018)'in Hindistan' da gerçekleştirdiği çalışma sonucuna göre ise yaş, cinsiyet, meslek, gelir düzeyi ve nitelikler gibi demografik özelliklerin online satın alma davranışı üzerinde hiçbir etkisi bulunmamaktadir.

Ülkemizde konu ile ilgili yapılan çalışmalardan biri olan Özgüven (2011)'in çalışmasına göre kadınlar, gençler, lisans ve lisansüstü mezunu ve orta gelirli kişilerin online alışverişe tutumları daha olumlu olup medeni durum ve meslekler online alışverişe karşı tutumda farklılık yaratmamaktadır. Turan (2011)'ın çalışmasına göre ise erkeklerin kadınlardan neredeyse iki katı oranda daha fazla İnternetten alışveriş yaptıkları ortaya çıkmıştır. İşler vd. (2014)'nin çalışmasında ise online alışverişe karşı tutumda cinsiyet ve gelir durumuna göre farklılık söz konusu olmayıp bekar, 21-30 yaş aralığında, lisans mezunu olanlar ile öğrenci ve çalışanların tutumları olumludur. Marangoz vd. (2019) çalışma sonuçları gençlerin daha fazla online alışveriş yaptığını, gelir düzeyi ve eğitim düzeyindeki artış ile İnternetten harcama miktarının artışının doğru orantılı, hanehalkı büyüklüğü ile ters orantılı olduğunu 
göstermektedir. Bilgilier (2019)'in çalışma sonuçları ise erkek, 22-25 yaş arası, yüksek aylık gelir düzeyine sahip kişilerin İnternetten satın almaya karşı olumlu tutum geliştirdiklerini göstermektedir.

Geleneksel satın alma tarzından vazgeçememe, online alışverişi güvensiz bulma gibi nedenler söz konusu olsa da İnternet üzerinden alışveriş Türk tüketicisinin giderek daha fazla benimsediği bir alışveriş tarzı olmaktadır (Bayrakdaroğlu ve Çakır, 2016). Bu nedenle İnternetten alışveriş yapanların online karar verme tarzlarının Sam ve Chatwin (2015) tarafından geliştirilmiş, Bayraktaroğlu vd. (2017) tarafından Türkçe'ye uyarlanmış yedi boyuta sahip ‘Online Tüketici Tarzları Envanteri' aracılığıyla ölçülmesi amaçlanmıştır. İlgili envanterde yer alan boyutlar ise aşağıda ifade edilmiştir:

- Alışkanlık Halinde Yüksek Kaliteye Duyarlı Tüketici: Tüketicinin satın alımlarında kaliteyi ne kadar gözettiği ve bu durumun alışkanlığa ne kadar dönüştüğü ölçülür. Yüksek kalite tüketici için öncelikli unsurdur. "Satın alımlarımda yüksek kalite benim için çok önemli bir unsurdur." ve "Sevdiğim markanın ürünlerini bulduğumda mutlaka satın alırım." ifadeleri ile ölçülmektedir.

- Markaya Duyarlı Tüketici: Tüketicilerin daha pahalı ve bilinen markaları satın almaya yönelimleri ölçülür. Tüketicilerin tercihi çok satan, tanınmış ve pahalı markalardan yana olmaktadır. "Tanınmış ulusal markalar benim için en iyisidir.", "Bir ürün ne kadar pahalı ise o kadar kalitelidir." ve "Çok satan markaları satın almayı tercih ederim." ifadeleri ile ölçülmektedir.

- Yenilikçi-Modaya Duyarlı Tüketici: Kararlarında yenilikçi ve moda bilincinde olan tüketicinin karakteristiği ölçülür. Moda bilinçleri yüksektir. Modaya uygun ürünleri seçmek ve en moda ürünleri sahip olmak önemlidir. "Genellikle en moda ürün(ler)e sahibimdir." ve "Modaya uygunluk ve çekicilik benim için çok önemlidir." ifadeleri ile ölçülmektedir.

- Fiyata Duyarlı Tüketici: Tüketicilerin fiyat farkındalığı ölçülür. En düşük fiyatla en iyisine sahip olma gayesinde olan tüketici profilidir. "Mümkün olduğunca indirimli fiyattan satın alırım.", "Genellikle daha düşük fiyatlı ürünleri tercih ederim." ve "Paramın karşılığında en iyisini bulmaya dikkat ederim." ifadeleri ile ölçülmektedir.

- Ürün Portatifliğine/Taşınabilirliğine Duyarlı Tüketici: Alımlarda ürün taşınabilirliği bilincinin etkisi ölçülür. Taşınabilir ve daha küçük boyutlu ürünleri tercih etme eğilimindedirler. “Ürünleri satın alırken portatif/taşınabilir olması benim için çok önemlidir.” ve “Bir ürünü, ne kadar küçük boyutlu ise o kadar çok tercih ederim." ifadeleri ile ölçülmektedir.

- Web Sitesi İçeriğine Duyarlı Tüketici: Tüketicinin online alışveriş yaptığı web sitesinin imkanları hakkında çok şey bilip bilmediği ve web sitesinin satın alımlarını etkileyip etkilemediği ölçülür. Web sitesinin gizlilik ve güvenliği tüketici için çok önemli olup iletişim kanallarına sahip olması, ürün arama alanı olması, ürün hakkında detaylı bilgi ve yorum sunması ve sosyal ağlarla bağlantısı olması beklenmektedir. "İnternetteki alışverişlerimde gizlilik ve güvenlik çok önemlidir.", "Web sitesinin, ürün sorgulama ve sipariş takibi için iletişim kanalları sunması çok önemlidir.", "Web sitesinin, ürün arama hizmeti sunması çok önemlidir.", "Web sitesinin, ürünler hakkında detaylı bilgi vermesi çok iyi olur.", "Web sitesinin, ürünler hakkındaki müşteri yorumlarını sunması çok iyi olur.", "Web sitesinin, 
sosyal ağlarla (Facebook, Twitter vb.) bağlantısının olması çok iyi olur, böylelikle ürün yorumlarını arkadaşlarımla paylaşabilirim." ifadeleri ile ölçülmektedir.

- Web Sitesi Arayüzüne Duyarl Tüketici: Alışveriş web sitesinin tasarımı ve kullanılan animasyonların satın alma davranışı üzerindeki etkisi ölçülür. Web sitesinin dizaynından ne kadar etkilendikleri öğrenilmeye çalışılır. Satın alma kararını web sitesi tasarımının etkilediği ve çok sayıda animasyon/efekt gibi uygulamalara maruz kalmaktan hoşlanmayan tüketici profilini temsil etmektedir. "İşletmelerin web sitelerinde çok sayıda animasyon/efekt izlemek zorunda kalmak sinir bozucudur." ve "İşletmelerin web sitelerinin tasarımı, satın alma kararı vermede en önemli faktörlerden biridir." ifadeleri ile ölçülmektedir.

\section{ARAŞTIRMANIN METODOLOJİSI}

\subsection{Araştırmanın Amacı, Modeli ve Hipotezler}

$\mathrm{Bu}$ çalışmanın ana amacı online alışveriş yapan tüketicilerin karar verme tarzlarının yaş, cinsiyet, medeni durum, eğitim düzeyi, meslek, aylık aile geliri gibi sosyo-demografik özelliklere göre farklılaşıp farklılaşmadığını incelemektir. Bu amaçla nicel araştırma deseni ile saha araştırması gerçekleştirilmiştir. Şekil 1'de araştırmanın modeli gösterilmektedir.

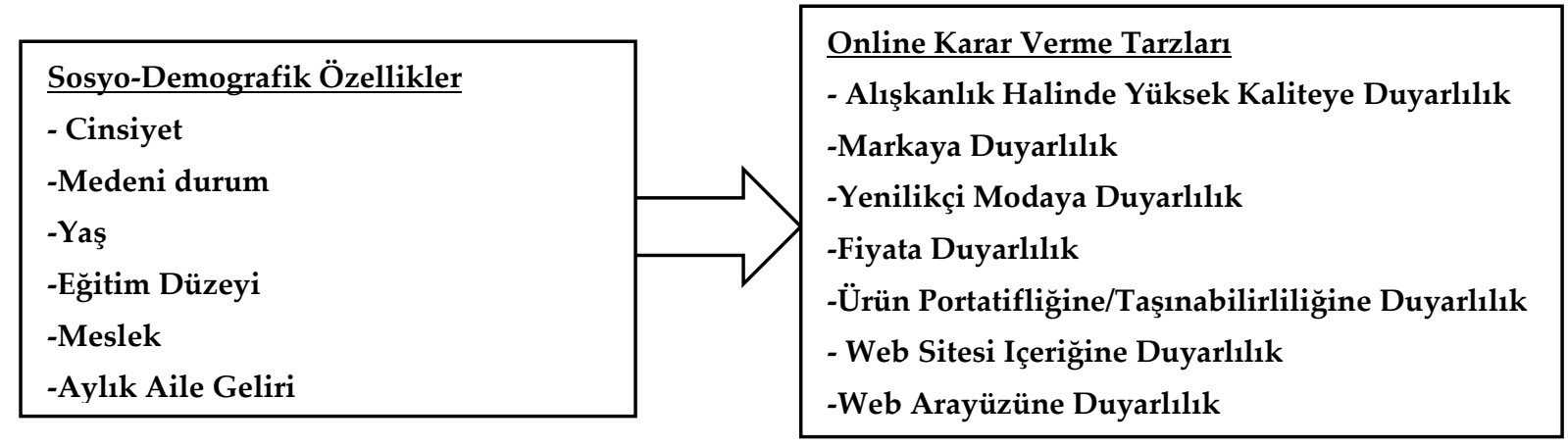

Şekil 1. Araştırma Modeli

Araştırmanın amacı ve modeli doğrultusunda test edilen ana hipoteze aşağıda yer verilmiştir: H1: Tüketicilerin online karar verme tarzları sosyo-demografik özellikleri itibariyle anlamlı bir farklılığa sahiptir.

H1 hipotezine bağlı olarak tüketicilerin cinsiyet, medeni durum, yaş, eğitim düzeyi, meslek ve aylık aile geliri gibi sosyo-demografik özellikleri esas alınarak aşağıdaki alt hipotezler oluşturulmuştur:

H1a: Tüketicilerin online karar verme tarzları cinsiyetlerine göre anlamlı bir farkhlı̆̆a sahiptir.

H1b: Tüketicilerin online karar verme tarzları medeni durumlarma göre anlamlı bir farkhlı̆̆a sahiptir.

H1c: Tüketicilerin online karar verme tarzları yaşlarına göre anlamlı bir farklılı̆̆a sahiptir.

H1d: Tüketicilerin online karar verme tarzları eğitim düzeylerine göre anlamlı bir farklılı̆̆a sahiptir.

H1e: Tüketicilerin online karar verme tarzları mesleklerine göre anlamlı bir farklılı̆̆a sahiptir.

H1f: Tüketicilerin online karar verme tarzları aylık aile gelir düzeylerine göre anlamlı bir farklılı̆̆a sahiptir. 


\subsection{Araştırmanın Örneklem Seçimi ve Veri Toplama Süreci}

Araştırmanın ana kütlesi 18 yaş üstü online alışveriş yapan kişilerden oluşmaktadır. Ana kütle sayısının tam belli olmaması, zaman ve maliyet açısından tesadüfi olmayan örnekleme yöntemlerinden kolayda örnekleme yöntemi tercih edilmiştir.

Araştırma verileri online anket yöntemi ile toplanmıştır. Anket çalışması için öncelikle 25 kişi üzerinde pilot uygulama gerçekleştirilmiş ve daha sonra hazırlanmış olan online anket katılımcılara ilgili link aracılığıyla ulaştırılarak veriler toplanmıştır. Anketin ulaştırıldığı kişilere daha önce online alışveriş yapıp yapmadıklarına dair konulan filtre soruya ‘Evet'cevabını veren yani daha önce online alışveriş yapmış 341 katılımcının cevapları değerlendirmeye alınmıştır.

Tüketicilerin online satın alma tarzlarını ölçmek için Sproles ve Kendall (1986) tarafından Tüketici Tarzları Envanteri olarak oluşturulmuş, Sam ve Chatwin (2015) tarafından Online Tüketici Tarzları Envanteri olarak geliştirilmiş ve ülkemiz kültürü açısından incelenebilmesi amacıyla Bayraktaroğlu vd. (2017) tarafından Türkçe'ye uyarlanmış, geçerlilik ve güvenilirlik analizleri yapılmış 'Online Karar Verme Tarzları' ölçeğinden yararlanılmıştır. Buna göre alışkanlık halinde yüksek kaliteye, markaya, yenilikçi modaya, fiyata, ürün portatifliğine/taşınabilirliğine, web sitesi içeriğine, web sitesi arayüzüne duyarlılık olmak üzere yedi boyut altında 20 soru mevcuttur. Sorularda 5'li likert ölçeği (1=Kesinlikle katılmıyorum, 5= Kesinlikle katılıyorum) kullanılmıştır.

\subsection{Verilerin Analizinde Kullanılan Yöntemler}

Araştırmada veriler SPSS ve AMOS programı kullanılarak analiz edilmiştir. Ölçeğin yapısal geçerliliğini incelemek için keşfedici faktör analizi uygulanmış ve faktör yapıları doğrulayıcı faktör analizi ile doğrulanmıştır ve iç tutarlılığın tespiti için Cronbach Alpha katsayısına bakılmıştır.

Hipotezlerin test edilmesinde ise $\mathrm{T}$ testi ve tek yönlü varyans analizinden yararlanılarak anlamlı farklılık olup olmadığ farklılıklar olduğunu tespit etmek amacıyla ise Post Hoc Tukey testi yapılmıştır.

\section{ARAŞTIRMA BULGULARI}

\subsection{Araştırma Örneklemine İlişkin Bulgular}

Araştırma kapsamında toplanan veriler SPSS programıla analiz edilmiştir. Katılımcıların sosyo-demografik özellikleri frekans analizi sonuçlarına göre aşağıdaki Tablo 1'de gösterilmiştir. 
Tablo 1. Katılımcıların Sosyo-Demografik Özellikleri

\begin{tabular}{|c|c|c|c|c|c|}
\hline Cinsiyet & $\mathrm{n}$ & $\%$ & Medeni durum & $\mathrm{n}$ & $\%$ \\
\hline Kadın & 205 & 60,1 & Bekar & 170 & 49,9 \\
\hline Erkek & 136 & 39,9 & Evli & 171 & 50,1 \\
\hline Toplam & 341 & 100 & Toplam & 341 & 100 \\
\hline Yaş & $\mathbf{n}$ & $\%$ & Öğrenim Düzeyi & $\mathbf{n}$ & $\%$ \\
\hline $18-25$ & 115 & 33,7 & Lise & 22 & 6,5 \\
\hline $26-35$ & 109 & 32 & Üniversite & 234 & 68,6 \\
\hline $36-45$ & 75 & 22 & Yüksek Lisans/Doktora & 85 & 24,9 \\
\hline 46 ve üzeri & 42 & 12,3 & \begin{tabular}{|l|} 
Toplam \\
\end{tabular} & 341 & 100 \\
\hline Toplam & 341 & 100 & Aile aylık gelir düzeyi & $\mathbf{n}$ & $\%$ \\
\hline Meslek & $\mathbf{n}$ & $\%$ & 5000 TL ve altı & 126 & 37 \\
\hline Çalışmayanlar & 103 & 30,2 & $5001-10.000 \mathrm{TL}$ & 143 & 41,9 \\
\hline Özel sektör çalışanı & 115 & 33,7 & 10001 TL ve üzeri & 72 & 21,1 \\
\hline Kamu sektörü çalışanı & 87 & 25,5 & Toplam & 341 & 100 \\
\hline İşyeri sahibi & 25 & 7,3 & & & \\
\hline Emekli & 11 & 3,2 & & & \\
\hline Toplam & 341 & 100 & & & \\
\hline
\end{tabular}

Araştırmaya katılanların demografik özellikleri hakkında bilgi veren Tablo 1 incelendiğinde, cinsiyet açısından katılımcıların yarısından fazlasının kadın $(\% 60,1), 18-35$ yaş arası $(\% 65,7)$ ve üniversite mezunu $(\% 68,6)$ olduğu demogarafik bulgular arasında yer almaktadır. Katılımcıların medeni durumlarına bakıldığında, katılımcıların birbirine yakın çok bir dağılım izledikleri görülmektedir. Katılımcılar arasında çalışmayanlar ve özel sektör çalışanları büyük çoğunluğu oluşturmakta ve aylık aile gelirleri 5001-10.000 TL arasında olan katılımcılar $(\% 41,9)$ en büyük orana sahiptir.

\subsection{Araştırma Ölçeğinin Geçerlilik, Güvenilirlik ve Normallik Analizi Sonuçları}

Online karar verme tarzları ölçeğinin yapısal geçerliliğini ölçmek amacıyla öncelikle SPSS 22 programı ile keşfedici faktör analizi yapılmıştır. Keşfedici faktör analizi çerçevesinde yapılan KMO örneklem yeterliliği testi örneklemden elde edilen veri yapısının faktör analizi için yeterli olup olmadığını göstermekte olup (Gürbüz ve Şahin, 2018) analiz sonucuna göre Kaiser-Meyer-Olkin (KMO) katsayısı .754 çıkmıştır. Barlett Küresellik testi ise değişkenler arası ilişkilerin oluşturmuş olduğu matrisin faktör analizi için yeterli olup olmadığını gösterir ve sonucun anlamlı çıkması gerekir (Gürbüz ve Şahin, 2018). Testin sonucu anlamlı çıkmıştır $(\mathrm{p}<0,05)$. KMO katsayısının .70'ten büyük ve Barlett testinin anlamlı çıkması dolayısıyla verilerin faktör analizine uygun olduğu sonucuna ulaşılabilmektedir. Ölçeklerin yapısal geçerliliklerine dair incelemeler varimax eksen döndürme tekniği ve temel bileşenler analizi ile yapılmış olup birden fazla faktöre yüklenen markaya duyarlılık ile ilgili ‘Bir ürün ne kadar pahalı ise o kadar kalitelidir." ifadesi analizden çıkartılmıştır. Web sitesi içeriğine duyarlılık ile ilgili ‘Web sitesinin, sosyal ağlarla (Facebook, Twitter vb.) bağlantısının olması çok iyi olur, böylelikle ürün yorumlarını arkadaşlarımla paylaşabilirim.' ifadesi ise web arayüzüne duyarlılık ile ilgili alt faktöre yüksek oranda yüklenmesi (\%70 üzerinde) ve ifade olarak da ilgili faktöre yüklenmesinin anormallik teşkil etmediği düşünülerek tamamen silinmesi yerine web arayüzüne duyarlılık faktörüne dahil edilerek çalışmaya devam 
edilmiştir. Keşfedici faktör analizi sonucuna göre aynı ölçeğin kullanıldığı Saltan ve Bilginer Özsaatcı (2020)'nin çalışmasındaki olduğu gibi yüksek kaliteye, modaya ve yenilikçi modaya duyarlılık tek faktör altında toplanmış olup nihai halinde ölçek beş boyut ve 19 maddeden oluşmaktadır. Tek boyutlu ölçeklerde tüm faktörlerin açıkladıkları toplam varyansın en az \%30, çok boyutlu ölçeklerde ise en az \%50 olması önerilmekte olup (Gürbüz ve Şahin, 2018) beş alt boyutta toplanan ifadelerin açıkladığı toplam varyans \%57,57 olup \%50 üzerindedir.

Keşfedici faktör analizinden sonra ise eldeki verilerle yapının doğrulanıp doğrulanmadığını kontrol etmek için Amos 26 programı ile doğrulayıcı faktör analizi yapılmıştır. Ölçeğin beş faktör altında toplandığı doğrulanmış, elde edilen model uyum ve eşik değerlerinin iyi uyum ve kabul edilebilir uyum değerleri arasında olduğu belirlenmiş olup ilgili değerler Tablo 2' de gösterilmiştir.

Tablo 2. Uyum Değerleri ve Analiz Sonuçları

\begin{tabular}{lcccc}
\hline Uyum Ölçütü & İyi Uyum & Kabul Edilebilir Uyum & Model Değerleri & Uyum Derecesi \\
\hline CMIN/DF & $\leq 3$ & $\leq 5$ & 2,56 & İyi Uyum \\
\hline GFI & $\geq 90$ & $80-89$ & 0,9 & Iyyi Uyum \\
\hline AGFI & $\geq 90$ & $80-89$ & 0,86 & Kabul Edilebilir Uyum \\
\hline CFI & $\geq 90$ & $80-89$ & 0,87 & Kabul Edilebilir Uyum \\
\hline RMSEA & $\leq 0,05$ & $\leq 0,08$ & 0,068 & Kabul Edilebilir Uyum \\
\hline
\end{tabular}

Kaynak (Uyum Değerleri): Corral ve Calvete, 2000

Daha sonraki aşamada ise veri setlerinin güvenilirliğini ölçmek amacıyla güvenilirlik analizi yapılmıştır. Güvenilirlik, bir ölçme aracının ne kadar tutarlı ölçüm yaptığını göstermekte olup sosyal bilimlerde en fazla iç tutarlılık güvenilirliği tercih edilmektedir. İç tutarlılık güvenilirliği ise ölçme aracında yer alan maddelerin kendi aralarındaki tutarlılığ göstermektedir (Gürbüz ve Şahin, 2018). İç tutarlılık güvenilirliği ölçümü için Cronbach alfa değeri hesaplanmış ve güvenilirlik katsayısı 696 çıkmıştır. Ölçeğin iç tutarlılık güvenilirliğine sahip kabul edilmesi için ilgili değerin en az .70 olması gerekmekte olup (Gürbüz ve Şahin, 2018) araştırmada kullanılan ölçeğin güvenilir olarak kabul edilen alt sınırda olması ölçeğin güvenilir olduğunu göstermektedir.

Hipotez testleri yapılmadan önce verilerin, parametrik veya nonparametrik test koşullarından hangisini sağladığını tespit etmek yani verilerin normal dağılım gösterip göstermediğine bakılması gerekir. Bu amaçla ölçeklerin çarpıklık (skewness) ve basıklık (kurtosis) değerlerine bakılmıştır. Kline (2011) verilerin normal dağılım gösterdiklerini kabul etmek için çarpıklık mutlak değerinin üçten ve basıklık mutlak değerinin ondan küçük olması gerektiğini belirtmektedir. Kullandığımız ölçekte ise yüksek kaliteye, markaya ve yenilikçi modaya duyarlılık alt boyutunun çarpıklık/basıklık değerleri 0,006/-0,436, fiyata duyarlılık alt boyutunun çarpıklık/basıklık değerleri -0,535/0,031, ürün taşınabilirliği/portatifliğine duyarlılık alt boyutunun çarpıklık/basıklık değerleri $-0,100 /-0,187$, web sitesi içeriğine duyarlılık alt boyutunun çarpıklık/basıklık değerleri -2,068/3,734, web arayüzüne duyarlılık alt boyutunun çarpıklık/basıklık değerleri ise $-0,434 /-0,344$ olup verilerin normal dağılım gösterdikleri kabul edilerek verilerin analizinde istatistiksel gücü daha yüksek olan parametrik testlerden yararlanılmasına karar verilmiştir. 


\subsection{Hipotez Testleri ve Bulgular}

Hipotezlerin test edilmesi aşamasında online karar verme tarzları ile iki bağımsız gruba sahip cinsiyet ve medeni durum değişkenleri arasında istatistiksel olarak anlamlı bir farklılık olup olmadığını tespit etmek için bağımsız örneklem T testinden, ikiden fazla bağımsız gruba sahip yaş, eğitim düzeyi, meslek ve aylık aile geliri değişkenler ile arasında istatistiksel olarak anlamlı bir farklılık olup olmadığını tespit etmek için tek yönlü varyans analizinden(ANOVA), varyans analizi sonucunda hangi gruplar arasında farklılıklar olduğunun tespiti için Post Hoc Tukey testinden yararlanılmıştır.

H1: Tüketicilerin online karar verme tarzları sosyo-demografik özellikleri itibariyle anlamlı bir farklılı̆̆a sahiptir.

H1 hipotezine bağlı olarak alt hipotezler test edilmiştir.

H1a: Tüketicilerin online karar verme tarzları cinsiyetlerine göre anlamlı bir farklılı̆̆a sahiptir.

Tüketicilerin; online karar verme tarzlarına ilişkin görüşlerinin cinsiyete göre anlamlı farklılık gösterip göstermediği araştırılmıştır. Bu amaçla yapılan $\mathrm{T}$ testi sonuçları Tablo 3 'te yer almaktadır.

Tablo 3. Cinsiyet Açısından Bağımsız Gruplar İçin T Testi Analiz Sonuçları

\begin{tabular}{|c|c|c|c|c|c|c|}
\hline \multirow{2}{*}{$\begin{array}{l}\text { Online Karar Verme Tarzları Alt } \\
\text { Faktörleri }\end{array}$} & \multirow{2}{*}{ Cinsiyet } & \multirow{2}{*}{ n } & \multirow{2}{*}{ Ortalama } & \multirow{2}{*}{$\begin{array}{c}\text { Standart } \\
\text { Sapma } \\
\end{array}$} & \multicolumn{2}{|c|}{ T Testi } \\
\hline & & & & & T değeri & $P$ değeri \\
\hline \multirow{2}{*}{$\begin{array}{l}\text { Yenilikçi modaya, markaya ve } \\
\text { yüksek kaliteye duyarlılık }\end{array}$} & Kadın & 205 & 3,03 & 0,88 & \multirow{2}{*}{1,871} & \multirow{2}{*}{0,062} \\
\hline & Erkek & 136 & 3,21 & 0,84 & & \\
\hline \multirow{2}{*}{ Fiyata duyarlılık } & Kadın & 205 & 3,95 & 0,68 & \multirow{2}{*}{0,918} & \multirow{2}{*}{0,360} \\
\hline & Erkek & 136 & 3,88 & 0,68 & & \\
\hline \multirow{2}{*}{$\begin{array}{l}\text { Ürün taşınabilirliği/portatifliğine } \\
\text { duyarlılık }\end{array}$} & Kadın & 205 & 3,41 & 0,91 & \multirow{2}{*}{2,508} & \multirow{2}{*}{0,013} \\
\hline & Erkek & 136 & 3,15 & 0,93 & & \\
\hline \multirow{2}{*}{ Web sitesi içeriğine duyarlılık } & Kadın & 205 & 4,82 & 0,33 & \multirow{2}{*}{2,473} & \multirow{2}{*}{0,014} \\
\hline & Erkek & 136 & 4,70 & 0,51 & & \\
\hline \multirow{2}{*}{ Web arayüzüne duyarlılık } & Kadın & 205 & 4,06 & 0,73 & \multirow{2}{*}{1,603} & \multirow{2}{*}{0,110} \\
\hline & Erkek & 136 & 3,93 & 0,71 & & \\
\hline
\end{tabular}

Tablo 3'te görüldügü gibi \%95 güven düzeyinde tüketicilerin cinsiyeti ile ürünlerin portatifliğine/taşınabilirliğine duyarlı $(p=, 013)$ ve web sitesi içeriğine duyarlı $(p=, 014)$ online karar verme tarzları arasında istatistiksel olarak anlamlı bir farklılık söz konusudur. Diğer faktörler cinsiyet açısından anlamlı bir farklılı̆̆a sahip değildir. Ortalamaları açısından incelendiğinde ise kadınlar online alışverişlerinde ürün portatifliği/taşınabilirliğine ve web sitesi içeriğine daha duyarlı karar vermektedirler. Sonuç olarak tüketicilerin online karar alma tarzları cinsiyetlerine göre anlamlı bir farklılığa sahip olup H1a hipotezi kısmen kabul edilmiştir.

H1b: Tüketicilerin online karar verme tarzları medeni durumlarına göre anlamlı bir farklılı̆̆a sahiptir.

Tüketicilerin; online karar verme tarzlarına ilişkin görüşlerinin medeni durumlarına göre anlamlı farklılık gösterip göstermediği araştırılmıştır. Bu amaçla yapılan $\mathrm{T}$ testi sonuçları Tablo 4 'te yer almaktadir. 
Tablo 4. Medeni Durum Açısından Bağımsız Gruplar İçin T Testi Analiz Sonuçları

\begin{tabular}{|c|c|c|c|c|c|c|}
\hline \multirow{2}{*}{$\begin{array}{l}\text { Online Karar Verme Tarzları Alt } \\
\text { Faktörleri }\end{array}$} & \multirow{2}{*}{$\begin{array}{l}\text { Medeni } \\
\text { Durum }\end{array}$} & \multirow{2}{*}{$\mathbf{n}$} & \multirow{2}{*}{ Ortalama } & \multirow{2}{*}{$\begin{array}{c}\text { Standart } \\
\text { Sapma }\end{array}$} & \multicolumn{2}{|c|}{ T Testi } \\
\hline & & & & & T değeri & P değeri \\
\hline \multirow{2}{*}{$\begin{array}{l}\text { Yenilikçi modaya, markaya ve } \\
\text { yüksek kaliteye duyarlılık }\end{array}$} & Bekar & 170 & 3,23 & 0,89 & \multirow{2}{*}{2,596} & \multirow{2}{*}{0,010} \\
\hline & Evli & 171 & 2,98 & 0,83 & & \\
\hline \multirow{2}{*}{ Fiyata duyarlılık } & Bekar & 170 & 3,95 & 0,67 & \multirow{2}{*}{0,763} & \multirow{2}{*}{0,446} \\
\hline & Evli & 171 & 3,89 & 0,69 & & \\
\hline \multirow{2}{*}{$\begin{array}{l}\text { Ürün taşınabilirliği/portatifliğine } \\
\text { duyarlılık }\end{array}$} & Bekar & 170 & 3,32 & 0,91 & \multirow{2}{*}{0,194} & \multirow{2}{*}{0,847} \\
\hline & Evli & 171 & 3,30 & 0,94 & & \\
\hline \multirow{2}{*}{ Web sitesi içeriğine duyarlılık } & Bekar & 170 & 4,72 & 0,48 & \multirow{2}{*}{$-2,249$} & \multirow{2}{*}{0,025} \\
\hline & Evli & 171 & 4,82 & 0,33 & & \\
\hline \multirow{2}{*}{ Web arayüzüne duyarlılık } & Bekar & 170 & 4,06 & 0,77 & \multirow{2}{*}{1,217} & \multirow{2}{*}{0,225} \\
\hline & Evli & 171 & 3,96 & 0,68 & & \\
\hline
\end{tabular}

Tablo 4'e göre \%95 güven düzeyinde tüketicilerin medeni durumları ile yüksek kaliteye, yenilikçi modaya ve markaya $(p=, 010)$ ve web sitesi içeriğine duyarlı $(p=, 025)$ online karar verme tarzları arasında istatistiksel olarak anlamlı bir farklılık söz konusudur. Ortalamalar incelendiğinde ise online alışverişlerde bekarlar yenilikçi modaya, markaya ve yüksek kaliteye duyarlı, evliler ise web sitesi içeriğine duyarlı satın alma kararı vermektedirler. Sonuç olarak tüketicilerin online karar alma tarzları medeni durumlarına göre anlamlı bir farklılığa sahip olup H1b hipotezi kısmen kabul edilmiştir.

H1c: Tüketicilerin online karar verme tarzları yaşlarına göre anlamlı bir farkhlı̆̆a sahiptir.

Tüketicilerin; online karar verme tarzlarına ilişkin görüşlerinin yaşlarına göre anlamlı farklılık gösterip göstermediği araştırılmıştır. Bu amaçla yapılan tek yönlü varyans analizi sonuçları Tablo 5'te yer almaktadir.

Tablo 5. Yaş Değişkenine Göre Tek Yönlü Varyans Analizi Sonuçları

\begin{tabular}{|c|c|c|c|c|c|c|}
\hline \multirow{2}{*}{$\begin{array}{l}\text { Online Satın Alma Karar Tarzları Alt } \\
\text { Faktörleri }\end{array}$} & \multirow{2}{*}{ Yaş } & \multirow{2}{*}{$\mathbf{n}$} & \multirow{2}{*}{ Ortalama } & \multirow{2}{*}{$\begin{array}{c}\text { Standart } \\
\text { Sapma }\end{array}$} & \multicolumn{2}{|c|}{ Varyans Analizi } \\
\hline & & & & & F değeri & $P$ değer \\
\hline \multirow{4}{*}{$\begin{array}{l}\text { Yenilikçi modaya, markaya ve yüksek kaliteye } \\
\text { duyarlılık }\end{array}$} & $18-25$ & 115 & 3,3 & 0,94 & \multirow{4}{*}{3,804} & \multirow{4}{*}{0,01} \\
\hline & $26-35$ & 109 & 3,06 & 0,86 & & \\
\hline & $36-45$ & 75 & 3,04 & 0,76 & & \\
\hline & 46 ve üzeri & 42 & 2,81 & 0,77 & & \\
\hline \multirow{4}{*}{ Fiyata duyarlılık } & $18-25$ & 115 & 3,99 & 0,66 & \multirow{4}{*}{2,113} & \multirow{4}{*}{0,098} \\
\hline & $26-35$ & 109 & 3,94 & 0,69 & & \\
\hline & $36-45$ & 75 & 3,9 & 0,64 & & \\
\hline & 46 ve üzeri & 42 & 3,69 & 0,76 & & \\
\hline \multirow{4}{*}{ Ürün taşınabilirliği/portatifliğine duyarlılık } & $18-25$ & 115 & 3,28 & 0,86 & \multirow{4}{*}{0,609} & \multirow{4}{*}{0,609} \\
\hline & $26-35$ & 109 & 3,33 & 0,94 & & \\
\hline & $36-45$ & 75 & 3,39 & 0,92 & & \\
\hline & 46 ve üzeri & 42 & 3,17 & 1,06 & & \\
\hline \multirow{4}{*}{ Web sitesi içeriğine duyarlılık } & $18-25$ & 115 & 4,69 & 0,52 & \multirow{4}{*}{2,153} & \multirow{4}{*}{0,093} \\
\hline & $26-35$ & 109 & 4,83 & 0,34 & & \\
\hline & $36-45$ & 75 & 4,79 & 0,38 & & \\
\hline & 46 ve üzeri & 42 & 4,8 & 0,31 & & \\
\hline \multirow{4}{*}{ Web arayüzüne duyarlılık } & $18-25$ & 115 & 4,05 & 0,78 & \multirow{4}{*}{2,079} & \multirow{4}{*}{0,103} \\
\hline & $26-35$ & 109 & 4,09 & 0,68 & & \\
\hline & $36-45$ & 75 & 3,97 & 0,68 & & \\
\hline & 46 ve üzeri & 42 & 3,78 & 0,74 & & \\
\hline
\end{tabular}


Tablo 5'e göre \%95 güven düzeyinde tüketicilerin yaşları ile yüksek kaliteye, markaya ve yenilikçi modaya duyarlı( $\mathrm{p}=, 01)$ online karar verme tarzları arasında istatitiksel olarak anlamlı bir farklılık söz konusudur. Anlamlı farklılığın hangi gruplar arasında olduğunu belirlemek için yapılan Tukey karşılaştırma testi sonucunda 18- 25 yaş grubu ile 46 ve üzeri yaş grubu arasında 18-25 yaş grubu lehine istatistiksel olarak $(\mathrm{p}<0,05)$ anlamlı bir farklılık saptanmıştır. Bu durum, 18-25 yaş grubundaki tüketicilerin yüksek kaliteye, markaya ve yenilikçi modaya daha duyarlı online satın alma kararı verdiğini göstermektedir. Diğer alt boyutlar arasındaki farklılık istatistiksel olarak anlamlı bulunmamıştır. Sonuç olarak tüketicilerin online karar alma tarzları yaşlarına göre anlamlı bir farklılık göstermekte olup H1c hipotezi kısmen kabul edilmiştir.

H1d: Tüketicilerin online karar verme tarzları eğitim düzeylerine göre anlamlı bir farklhlı̆̆a sahiptir.

Tüketicilerin; online karar verme tarzlarına ilişkin görüşlerinin eğitim düzeylerine göre anlamlı farklılık gösterip göstermediği araştırılmıştır. Bu amaçla yapılan tek yönlü varyans analizi sonuçları Tablo 6'da yer almaktadır.

Tablo 6. Eğitim Düzeyi Değişkenine Göre Tek Yönlü Varyans Analizi Sonuçları

\begin{tabular}{|c|c|c|c|c|c|c|}
\hline \multirow{2}{*}{$\begin{array}{l}\text { Online Satın Alma Karar } \\
\text { Tarzları Alt Faktörleri }\end{array}$} & \multirow{2}{*}{ Eğitim Düzeyi } & \multirow{2}{*}{$\mathbf{n}$} & \multirow{2}{*}{ Ortalama } & \multirow{2}{*}{$\begin{array}{l}\text { Standart } \\
\text { Sapma }\end{array}$} & \multicolumn{2}{|c|}{ Varyans Analizi } \\
\hline & & & & & F değeri & P değeri \\
\hline \multirow{3}{*}{$\begin{array}{l}\text { Yenilikçi modaya, markaya ve } \\
\text { yüksek kaliteye duyarlılık }\end{array}$} & Lise & 22 & 3,14 & 0,82 & \multirow{3}{*}{0,058} & \multirow{3}{*}{0,943} \\
\hline & Üniversite & 234 & 3,11 & 0,90 & & \\
\hline & Yüksek Lisans/Doktora & 85 & 3,08 & 0,80 & & \\
\hline \multirow{3}{*}{ Fiyata duyarlılık } & Lise & 22 & 4,03 & 0,67 & \multirow{3}{*}{0,830} & \multirow{3}{*}{0,437} \\
\hline & Üniversite & 234 & 3,93 & 0,66 & & \\
\hline & Yüksek Lisans/Doktora & 85 & 3,85 & 0,73 & & \\
\hline \multirow{3}{*}{$\begin{array}{l}\text { Ürün } \\
\text { taşınabilirliği/portatifliğine } \\
\text { duyarlılık }\end{array}$} & Lise & 22 & 3,09 & 0,95 & \multirow{3}{*}{0,670} & \multirow{3}{*}{0,512} \\
\hline & Üniversite & 234 & 3,32 & 0,87 & & \\
\hline & Yüksek Lisans/Doktora & 85 & 3,34 & 1,07 & & \\
\hline \multirow{3}{*}{ Web sitesi içeriğine duyarlılık } & Lise & 22 & 4,83 & 0,30 & \multirow{3}{*}{0,938} & \multirow{3}{*}{0,392} \\
\hline & Üniversite & 234 & 4,75 & 0,45 & & \\
\hline & Yüksek Lisans/Doktora & 85 & 4,81 & 0,33 & & \\
\hline \multirow{3}{*}{ Web arayüzüne duyarlılık } & Lise & 22 & 4,14 & 0,91 & \multirow{3}{*}{0,809} & \multirow{3}{*}{0,446} \\
\hline & Üniversite & 234 & 4,03 & 0,71 & & \\
\hline & Yüksek Lisans/Doktora & 85 & 3,94 & 0,74 & & \\
\hline
\end{tabular}

Tablo 6'ya göre \%95 güven düzeyinde tüketicilerin eğitim düzeyleri ile online karar verme tarzları arasında anlamlı bir farklılık bulunamamıştır $(\mathrm{p}>0,05)$. Bu nedenle H1d hipotezi reddedilmiştir.

H1e: Tüketicilerin online karar verme tarzları mesleklerine göre anlamlı bir farklılığa sahiptir.

Tüketicilerin; online karar verme tarzlarına ilişkin görüşlerinin mesleklerine göre anlamlı farklılık gösterip göstermediği araştırılmıştır. Bu amaçla yapılan tek yönlü varyans analizi sonuçları Tablo 7'de yer almaktadır. 
Tablo 7. Meslek Değişkenine Göre Tek Yönlü Varyans Analizi Sonuçları

\begin{tabular}{|c|c|c|c|c|c|c|}
\hline \multirow{2}{*}{$\begin{array}{l}\text { Online Satın Alma Karar } \\
\text { Tarzları Alt Faktörleri }\end{array}$} & \multirow{2}{*}{ Meslek } & \multirow{2}{*}{$\mathbf{n}$} & \multirow{2}{*}{ Ortalama } & \multirow{2}{*}{$\begin{array}{l}\text { Standart } \\
\text { Sapma }\end{array}$} & \multicolumn{2}{|c|}{ Varyans Analizi } \\
\hline & & & & & F değeri & P değeri \\
\hline \multirow{5}{*}{$\begin{array}{l}\text { Yenilikçi modaya, markaya ve } \\
\text { yüksek kaliteye duyarlılık }\end{array}$} & Çalışmayan & 103 & 3,09 & 0,91 & \multirow{5}{*}{0,712} & \multirow{5}{*}{0,584} \\
\hline & Özel sektör çalışanı & 115 & 3,17 & 0,90 & & \\
\hline & Kamu sektörü çalışanı & 87 & 3,12 & 0,84 & & \\
\hline & İşyeri sahibi & 25 & 2,86 & 0,73 & & \\
\hline & Emekli & 11 & 3,00 & 0,56 & & \\
\hline \multirow{5}{*}{ Fiyata duyarlılık } & Çalışmayan & 103 & 3,95 & 0,65 & \multirow{5}{*}{2,720} & \multirow{5}{*}{0,03} \\
\hline & Özel sektör çalışanı & 115 & 4,03 & 0,69 & & \\
\hline & Kamu sektörü çalışanı & 87 & 3,73 & 0,67 & & \\
\hline & İşyeri sahibi & 25 & 3,96 & 0,72 & & \\
\hline & Emekli & 11 & 3,79 & 0,65 & & \\
\hline \multirow{5}{*}{$\begin{array}{l}\text { Ürün taşınabilirliği/portatifliğine } \\
\text { duyarlılık }\end{array}$} & Çalışmayan & 103 & 3,26 & 0,83 & \multirow{5}{*}{2,045} & \multirow{5}{*}{0,088} \\
\hline & Özel sektör çalışanı & 115 & 3,40 & 0,91 & & \\
\hline & Kamu sektörü çalışanı & 87 & 3,22 & 1,02 & & \\
\hline & İşyeri sahibi & 25 & 3,58 & 0,81 & & \\
\hline & Emekli & 11 & 2,77 & 1,17 & & \\
\hline \multirow{5}{*}{ Web sitesi içeriğine duyarlılık } & Çalışmayan & 103 & 4,78 & 0,43 & \multirow{5}{*}{0,128} & \multirow{5}{*}{0,972} \\
\hline & Özel sektör çalışanı & 115 & 4,75 & 0,44 & & \\
\hline & Kamu sektörü çalışanı & 87 & 4,77 & 0,39 & & \\
\hline & İşyeri sahibi & 25 & 4,77 & 0,43 & & \\
\hline & Emekli & 11 & 4,84 & 0,25 & & \\
\hline \multirow{5}{*}{ Web arayüzüne duyarlılık } & Çalışmayan & 103 & 3,99 & 0,73 & \multirow{5}{*}{1,588} & \multirow{5}{*}{0,177} \\
\hline & Özel sektör çalışanı & 115 & 4,08 & 0,78 & & \\
\hline & Kamu sektörü çalışanı & 87 & 3,88 & 0,69 & & \\
\hline & İşyeri sahibi & 25 & 4,24 & 0,55 & & \\
\hline & Emekli & 11 & 4,00 & 0,67 & & \\
\hline
\end{tabular}

Tablo 7'ye göre \%95 güven düzeyinde tüketicilerin meslekleri ile fiyata duyarlı $(p=, 03)$ online karar verme tarzları arasında istatistiksel olarak anlamlı bir farklılık söz konusudur. Anlamlı farklılığın hangi gruplar arasında olduğunu belirlemek için yapılan Tukey karşılaştırma testi sonucunda özel sektör çalışanları ile kamu sektörü çalışanları arasında özel sektör çalışanları lehine istatistiksel olarak $(\mathrm{p}<0,05)$ anlamlı bir farklılık saptanmıştır. Bu durum, özel sektör çalışanların online alışverişlerde daha fiyata duyarlı satın alma kararı verdiğini göstermektedir. Diğer alt boyutlar arasındaki farklılık istatistiksel olarak anlamlı bulunmamıştır. Sonuç olarak tüketicilerin online karar alma tarzları ile meslekleri arasında anlamlı bir farklılık söz konusu olup H1e hipotezi kısmen kabul edilmiştir.

H1f: Tüketicilerin online karar verme tarzları aylık aile gelir düzeylerine göre anlamlı bir farklılı̆ga sahiptir.

Tüketicilerin; online karar verme tarzlarına ilişkin görüşlerinin aylık aile gelirlerine göre anlamlı farklılık gösterip göstermediği araştırılmıştır. Bu amaçla yapılan tek yönlü varyans analizi sonuçları Tablo 8'de yer almaktadır. 
Tablo 8. Aylık Aile Geliri Değişkenine Göre Tek Yönlü Varyans Analizi Sonuçları

\begin{tabular}{|c|c|c|c|c|c|c|}
\hline \multirow{2}{*}{ Online Karar Verme Tarzları Alt Faktörleri } & \multirow{2}{*}{$\begin{array}{l}\text { Aylık Aile Gelir } \\
\text { Düzeyi }\end{array}$} & \multirow{2}{*}{$\mathbf{n}$} & \multirow{2}{*}{ Ortalama } & \multirow{2}{*}{$\begin{array}{c}\text { Standart } \\
\text { Sapma }\end{array}$} & \multicolumn{2}{|c|}{ Varyans Analizi } \\
\hline & & & & & F değeri & P değeri \\
\hline \multirow{3}{*}{$\begin{array}{l}\text { Yenilikçi modaya, markaya ve yüksek } \\
\text { kaliteye duyarlılık }\end{array}$} & 5000 TL ve altı & 126 & 3,1323 & ,89971 & \multirow{3}{*}{0,152} & \multirow{3}{*}{0,859} \\
\hline & $5001-10.000 \mathrm{TL}$ & 143 & 3,0746 & 82808 & & \\
\hline & 10001 TL ve üzeri & 72 & 3,1134 & 89811 & & \\
\hline \multirow{3}{*}{ Fiyata duyarlılık } & 5000 TL ve alt1 & 126 & 4,0344 & ,68095 & \multirow{3}{*}{3,119} & \multirow{3}{*}{0,045} \\
\hline & $5001-10.000 \mathrm{TL}$ & 143 & 3,8718 & 69643 & & \\
\hline & 10001 TL ve üzeri & 72 & 3,8102 & 62255 & & \\
\hline \multirow{3}{*}{ Ürün taşınabilirliği/portatifliğine duyarlılık } & 5000 TL ve altı & 126 & 3,4563 & ,80255 & \multirow{3}{*}{4,888} & \multirow{3}{*}{0,008} \\
\hline & $5001-10.000 \mathrm{TL}$ & 143 & 3,3147 & ,91866 & & \\
\hline & 10001 TL ve üzeri & 72 & 3,0347 & 1,07247 & & \\
\hline \multirow{3}{*}{ Web sitesi içeriğine duyarlılık } & 5000 TL ve alt 1 & 126 & 4,7333 & ,45887 & \multirow{3}{*}{1,269} & \multirow{3}{*}{0,282} \\
\hline & $5001-10.000 \mathrm{TL}$ & 143 & 4,8112 & 37513 & & \\
\hline & 10001 TL ve üzeri & 72 & 4,7500 & ,41757 & & \\
\hline \multirow{3}{*}{ Web arayüzüne duyarlılık } & 5000 TL ve altı & 126 & 4,0847 & 74944 & \multirow{3}{*}{3,769} & \multirow{3}{*}{0,024} \\
\hline & $5001-10.000 \mathrm{TL}$ & 143 & 4,0490 & 69983 & & \\
\hline & 10001 TL ve üzeri & 72 & 3,8056 & ,71590 & & \\
\hline
\end{tabular}

Tablo 8'e göre \%95 güven düzeyinde tüketicilerin aylık aile gelir düzeyleri ile fiyata duyarlı $(p=, 0,045)$, ürün taşınabilirliği/portatifliğine duyarlı $(p=, 008)$ ve web arayüzüne duyarlı $(p=$, 024) online karar verme tarzları arasında istatistiksel olarak anlamlı bir farklılık tespit edilmiştir. Anlamlı farklılı̆̆ın hangi gruplar arasında olduğunu belirlemek için yapılan Tukey karşılaştırma testi sonucunda fiyata duyarlılık açısından 5.000 TL ve altı aylık gelire sahip olanlar ile 10.001 TL ve üzeri aylık gelire sahip olanlar arasında 5.000 TL ve altı aylık gelire sahip olanlar lehine istatistiksel olarak $(p<0,01)$ anlamlı bir farklılık saptanmıştır. Ürün taşınabilirliği/ portatifliği ile web arayüzüne duyarlılık açısında 5.000 TL ve altı aylık gelire sahip olanlar ile 10.001 TL ve üzeri aylık gelire sahip olanlar arasında 5.000 TL ve altı aylık gelire sahip olanlar lehine istatistiksel olarak $(p<0,05)$ anlamlı bir farklılık saptanmıştır. $\mathrm{Bu}$ durum, 5.000 TL ve altı aylık gelire sahip olanların online alışverişlerinde ürün portatifliğine ve web arayüzüne daha duyarlı satın alma kararı verdiğini göstermektedir. Diğer alt boyutlar arasındaki farklılık istatistiksel olarak anlamlı bulunmamıştır. Sonuç olarak tüketicilerin online karar alma tarzları ile aylık aile gelir düzeylerine göre anlamlı bir farklılık söz konusu olup H1f hipotezi kısmen kabul edilmiştir.

Yukarıdaki tablolardan anlaşılacağı üzere H1 hipotezi kısmen kabul edilmiştir. Başka bir ifade ile farklı sosyo-demografik özelliklere sahip olan tüketiciler online karar verme tarzları itibariyle de farklılık göstermektedir.

\section{SONUÇ VE ÖNERİLER}

Tüketicilerin online alışveriş tercihlerinin artarak devam ettiği günümüzde, bireyler farklı odak noktaları ve duyarlılıklarla satın alma kararı verebilmektedir. Tüketicilerin kişilik özellikleri, yaşam tarzları, kültürleri, gelir durumları, alışkanlıkları bu farklılıklarda belirleyici olmaktadır.

$\mathrm{Bu}$ çalışmada tüketicilerin online karar verme tarzları Sam ve Chatwin(2015) tarafından geliştirilmiş, Bayraktaroğlu vd.(2017) tarafından Türkçe'ye uyarlanan alışkanlık halinde yüksek kaliteye, markaya, yenilikçi modaya, fiyata, ürün portatifliğine/taşınabilirliğine, web sitesi içeriğine, web sitesi arayüzüne duyarlılık boyutları çerçevesinde ve sosyo-demografik özellikler açısından incelenmiş olup tüketicilerin cinsiyetleri ile online alışverişte ürün 
portatifliği/taşınabilirliğine ve web sitesi içeriğine duyarlı olarak karar verme tarzları arasında anlamlı bir farklılık tespit edilmiş ve kadınların erkeklere göre bu konularda daha duyarlı davrandıkları anlaşılmıştır. Tüketicilerin online alışverişlerinde cinsiyet ile markaya, yüksek kaliteye ve yenilikçi modaya duyarlılık arasında anlamlı bir farklılık ortaya çıkmamıştır. Kadınların erkeklere göre ürün portatiflik/ taşınabilirliğine daha duyarlı olmaları fizyolojik farklılıkları ile web sitesi içeriğine daha duyarlı olmaları ise detaycılık özelliği ile ürün hakkında daha fazla ve detaylı bilgi arama istekleri ile açıklanabilmektedir.

Medeni durum açısından yapılan analizlerde ise bekarların online alışverişlerinde yüksek kaliteye, markaya ve yenilikçi modaya duyarlı, evlilerin ise web sitesi içeriğine duyarlı karar verdikleri sonucuna ulaşılmıştır. Bu sonuç bekarların, daha çok beğenilme arzusuna sahip olmaları ve evlilik hayatının getirdiği birtakım sorumluluklara sahip olmamalarından dolayı tercihlerinde modayı önceliklendirmeleri ve sürekli yenilenen moda gelişmelerini evlilere göre daha yakından takip edebilmeleri ile açıklanabilmektedir. Evlilerin web sitesi içeriğine daha duyarlı olmaları ise evlilerin sadece kendilerinin değil aynı zamanda eş ve çocuklarının alışverişlerini de yaptıkları için kullandıkları web sitesinin güvenilir olması, detaylı bilgi, sorgulama ve takip ekranı gibi içeriklere sahip olması önem teşkil edebilmektedir.

Tüketicilerin yaşları ile online karar verme tarzları arasında anlamlı bir farklılık bulunmakta olup 18-25 yaş grubundaki tüketicilerin 46 yaş ve üzeri tüketicilere göre yüksek kaliteye, markaya ve yenilikçi modaya daha duyarlı karar verdikleri tespit edilmiştir. Gençlerde beğenilme duygusunun daha ön planda olması nedeniyle modayı yakından takip etmeleri, markalı ve kaliteli ürünleri tercih etmeleri söz konusu olmaktadır.

Tüketicilerin eğitim düzeyleri ile online karar verme tarzları arasında ise anlamlı bir farklılık tespit edilmemiştir. Günümüzde eğitim düzeyi düşük olan bir kişi markalı, kaliteli, yüksek fiyatlı ürünleri tercih edebilirken eğitim düzeyi yüksek olup kaliteyi ön planda tutmayan, markaya önem vermeyen, fiyata duyarlı satın alma kararı veren tüketiciler de söz konusu olabilmektedir. Dolayısıyla çalışma sonucuna göre eğitim düzeyi karar verme tarzları üzerinde etkili bir faktör olarak tespit edilmemiştir.

Tüketicilerin meslekleri açısından yapılan analizlerde ise online alışverişlerde özel sektör çalışanlarının kamu sektörü çalışanlarından fiyata karşı daha duyarlı satın alma karar tarzına sahip oldukları tespit edilmiştir. Ulaşılan sonuç özel sektör çalışanlarının kamu sektörü çalışanlarına göre iş güvencelerinin olmaması nedeniyle daha düşük fiyattan satın almayı tercih etmeleri ile açıklanabilmektedir.

Tüketicilerin online satın alma karar tarzları aylık aile gelir düzeyleri açısından anlamlı bir farklılığa sahip olup 5.000 TL ve altında aylık aile gelirine sahip tüketiciler 10.001 TL ve üzeri aylık aile gelirine sahip olan tüketicilerden fiyata, ürün portatifliğine ve web arayüzüne daha duyarlı satın alma karar tarzına sahiptirler. Gelir düzeyleri düşük olan tüketicilerin satın alma kararlarında düşük fiyatlı ürünleri ön planda tutmaları anlaşılabilir bir sonuç olmakla beraber düşük gelir düzeyine sahip olan tüketicilerin ürün portatifliğine duyarlı karar vermeleri ise genelde yaşam alanlarının daha küçük olması yani daha küçük metrekareli hanelerde yaşamaları dolayısıyla küçük boyutlu, portatif ürünleri tercih etmeleri ile açılanabilir.

Sonuç olarak elde edilen bulgular online alışverişlerde bekar ve 18-25 arasındaki tüketicilerin yenilikçi modaya, markaya ve yüksek kaliteye duyarlı, özel sektörde çalışan ve aylık aile 
gelirleri 5.000 TL ve altında olan tüketicilerin fiyata duyarlı, kadın ve aylık aile gelirleri 5.000 TL ve altında olan tüketicilerin ürün portatifliğine/taşınabilirliğine duyarlı, evli ve kadın tüketicilerin web sitesi içeriğine duyarlı, aylık aile geliri 5.000 TL ve altında olan tüketicilerin ise web arayüzüne duyarlı satın alma karar tarzına sahip olduklarını göstermektedir. Dolayısıyla araştırma sonucunda elde edilen verilerin literatüre sağlayacağı katkının yanı sıra çevrimiçi kanallar üzerinden ticaret yapan işletmelere özellikle müşteri segmentasyonu çalışmalarında yardımcı olacağı düşünülmektedir.

Gelecekteki çalışmalar için örneklem sayısının artırılması, online karar verme tarzları ile kişilik özellikleri gibi farklı değişkenler arasındaki ilişkinin incelenmesi veya nicel yöntemlerin yanında nitel yöntemlerle de araştırmanın çeşitlendirilmesi önerilmektedir.

\section{KAYNAKÇA}

Adıgüzel, A. T. (2010). Sanal Mağaza Atmosferini Etkileyen Özellikler ve Tüketici Tercihleri Üzerindeki Rolü: Online Tüketiciler Üzerine Bir Araştırma. Yüksek Lisans Tezi, Balıkesir Üniversitesi Sosyal Bilimler Enstitüsü, Balıkesir.

Alreck, P., \& Settle, R. (2002). The Hurried Consumer: Time-Saving Perceptions of Internet and Catalogue Shopping. Journal of Database Marketing and Customer Strategy Management, 10(1), 25-35.

Bae, S., \& Miller, J. (2009) Consumer Decision-Making Styles for Sport Apparel: Gender Comparisons Between College Consumers. Journal of Research, 4(1),40-45

Bakewell, C., Mitchell, V., \& Rothwell, M. (2006). UK Generation Y Male Fashion Consciousness. Journal of Fashion Marketing and Management, 10(2), 169-180.

Bayrakdaroğlu, F., Taşçığlu, M. ve Özkoç, H. (2017). Online Karar Verme Tarzları Ölçeğinin Türkçe'ye Uyarlanması. Pamukkale Üniversitesi Sosyal Bilimler Enstitüsü Dergisi, 28, 159169.

Bayrakdaroğlu, F. ve Çakır, H. (2016). Tüketicilerin Onlıne Alışverişlerine İlişkin Karar Alma Tarzlarının İncelenmesine Yönelik Bir Araştırma- A Research Towards Consumers' Decision-Makıng Styles Regarding Onlıne Purchasing Behavior. Mehmet Akif Ersoy Üniversitesi Sosyal Bilimler Enstitüsü Dergisi, 8(15), 266-284.

Bilgilier, H. (2019). Y Kuşağının İnternetten Alışverişe Yönelik Tutumları: Nicel Bir Araştırma. Erciyes İletişim Dergisi, 6(1), 487-512.

Corral, S., \& Calvete, E. (2000). Machiavellianism: Dimensionality of the Mach IV and Its Relation to Self-Monitoring in a Spanish Sample. The Spanish Journal of Psychology, 3(1), 3-13.

Enginkaya, E. (2006). Elektronik Perakendecilik Elektronik Alişveriş. Ege Academic Review, 6(1), 10-16.

Gökçek, H. (2020). Online Alışverişte Karar Verme Stilleri, Çelişki, Risk ve Memnuniyet. Hiperyayın, 1.Baskı, İstanbul. 
Gürbüz, S. ve Şahin, F. (2018). Sosyal Bilimlerde Araştırma Yöntemleri (5. Baskı). Ankara: Seçkin Yayıncilik.

İşler, D. B., Yarangümelioğlu, D. ve Öztürk, E. (2014). Online Tüketici Satın Alma Davranışlarını Etkileyen Faktörlere Yönelik Bir Durum Değerlendirilmesi: Isparta İlinde Bir Uygulama. Uluslararası Alanya İşletme Dergisi, 6(3), 77-94.

Kalia, P. (2016). Demographic Profile of Online Shoppers: An Overview. Indian Journal of Economics and Development, 12(1a), 37-41.

Kalyoncuoğlu, S. (2018). Tüketicilerin Online Alışverişlerindeki Sanal Kart Kullanımlarının Teknoloji Kabul Modeli ile İncelenmesi. Afyon Kocatepe Üniversitesi Sosyal Bilimler Dergisi, 20(2), 193-213.

Kavalcı, K. ve Ünal, S. (2016). Y ve Z Kuşaklarının Öğrenme Stilleri ve Tüketici Karar Verme Tarzları Açısından Karşılaştırılması / A Research on Comparing Consumer DecisionMaking Styles and Learning Styles in Terms of the Generation Y and Z. Atatürk Üniversitesi Sosyal Bilimler Enstitüsü Dergisi, 20(3), 1033-1050.

Kline, R.B. (2011). Principles and Practice of Structural Equation Modeling, 3rd ed New York: Guilford Press.

Li, H., Kuo, C., \& Rusell, M. G. (1999). The Impact of Perceived Channel Utilities, Shopping Orientations, and Demographics on the Consumer's Online Buying Behavior. Journal of Computer-Mediated Communication, 5(2).

Lysonski, S., \& Durvasula, S. (2013). Consumer Decision Making Styles in Retailing: Evolution of Mindsets and Psychological Impacts. Journal of Consumer Marketing, 30(1), 75-87.

Marangoz, M., Özkoç, H.H., Aydın, E. A. (2019). Tüketicilerin İnternet Üzerinden Alışveriş Davranışlarının Açıklanmasına Yönelik Bir Çalışma, Tüketici ve Tüketim Araştırmaları Dergisi, 11(1), 1-22.

Mitchell, V.-W., \& Walsh, G. (2004). Gender Differences in German Consumer DecisionMaking Styles. Journal of Consumer Behaviour, 3(4), 331-346.

Naseri, M., \& Elliott, G. (2011). Role of Demographics, Social Connectedness and Prior İnternet Experience in Adoption of Online Shopping: Applications for Direct Marketing. Journal of Targeting, Measurement and Analysis for Marketing, 19(2), 69-84.

Oskaybaş, K., Dursun, T. ve Yener, D. (2015). Online Alışverişte Tüketicilerin Tercihlerini Etkileyen Unsurların Belirlenmesi. Marmara Üniversitesi İktisadi ve İdari Bilimler Dergisi, 36(1), 119-135.

Özden, A. (2019). Etik Tüketici Davranışı: Marka Odaklı Karar Verme Tarzı ve Demografik Değişkenlere Göre İncelenmesi Üzerine Bir Araştırma. Anadolu Dergisi, 19(3), 215-238.

Özden, A. (2019). Pozitif Algının ve Tüketici Karar Verme Tarzlarının Y ve Z Kuşakları Açısından Karşılaştırılması. Gazi İktisat ve İşletme Dergisi, 5(1), 1-20.

Özgüven, N. (2011). Tüketicilerin Online Alışverişe Karşı Tutumları ile Demografik Özellikleri Arasındaki İlişkinin Analizi. KMÜ Sosyal ve Ekonomik Araştırmalar Dergisi, 13(21), 47-54. 
Potgieter, D., Wiese, M., \& Strasheim, A. (2013). Demographic Differences in Adult Consumers' Decision Making Styles in Tshwane South Africa. Journal of Family Ecology and Consumer Sciences, 41, 11-27.

Saltan, O. F. ve Bilginer Özsaatcı, F. G. (2020). Tüketicilerin Gelişime Açıklık Kişilik Özelliği İle Onlıne Alışverişlerdeki Karar Verme Tarzları Arasındaki İlişki. Uluslararası İktisadi ve İdari Incelemeler Dergisi, 26, 225-248.

Sam, K. M., \& Chatwin, C. (2015). Online Consumer Decision-Making Styles for Enhanced Understanding of Macau Online Consumer Behavior. Asia Pacific, 20(2), 100-107.

Sharma, V., \& Jain, R. (2018). Impact of Demographics on Online Buying Behaviour: An Exploratory Study of Consumers of Bhopal. Prastuti Journal of Management and Research, 7(1), 31-37.

Sproles, G. B., \& Kendall, E. L. (1986). A Methodology for Profiling Consumers' Decision Making Styles. The Journal of Consumer Affairs, 20(2), 267-279.

Sundu, M., Yaşar, O. (2017). Tüketici Karar Verme Stili ile Düşünme Stili İlişkisi. Uluslararası İktisadi ve İdari İncelemeler Dergisi, 16. UİK Özel Sayısı, 183-194.

Turan, A. H. (2008). İnternet Alışverişi Tüketici Davranışını Belirleyen Etmenler: Geliştirilmiş Teknoloji Kabul Modeli (E-TAM) ile Bir Model Önerisi. Akademik Bilişim. Çanakkale 18 Mart Üniversitesi: 723-731.

Turan, A.H. (2011). İnternet Alışverişi Tüketici Davranışını Belirleyen Etmenler: Planlı Davranış Teorisi (TBP) ile Ampirik Bir Test. Doğuş Üniversitesi Dergisi, 12(1), 128-143.

Türkiye İstatistik Kurumu (TUIK) (2019). Hane Halkı Bilişim Teknolojileri KullanımıAraştırması. İndirilme Tarihi:10 Ocak 2021, URL: https://data.tuik.gov.tr/Bulten/Index?p=HanehalkiBilisim-Teknolojileri-(BT)-Kullanim-Arastirmasi-2019-30574

Türkiye İstatistik Kurumu (TUİK) (2020). Hane Halkı Bilişim Teknolojileri KullanımıAraştırması. İndirilme Tarihi:10 Ocak 2021, URL:https://data.tuik.gov.tr/Bulten/Index?p=HanehalkiBilisim-Teknolojileri-(BT)-Kullanim-Arastirmasi-2020-33679

Usta, R. (2006) Tüketicilerin Demografik Özellikleri ve İnternetten Satın Alma Davranışı Üzerine Bir Araştırma. Kooperatifçilik, 41(3), 1-13.

Yang, C., \& Wu, C.-C. (2007). Gender and Internet Consumers' Decision-Making. CyberPsychology \& Behavior, 10(1), 86-91.

Yeniçeri, T. ve Özal, H. (2016). Tüketici Karar Verme Tarzlarının Cinsiyet Kimliğine Göre İncelenmesi. Pazarlama ve Pazarlama Araştırmaları Dergisi, 18, 135-168.

Yeniçeri, T. ve Özbezek, B. D. (2019). Tüketici Karar Verme Tarzları: Suriyeli Sığınmacılar Üzerine Bir Araştırma. BMIJ, 7(5), 2282-2298.

Yüksekbilgili, Z. (2016). Tüketici Karar Verme Tarzlarının Kuşaklara Göre Değerlendirilmesi Electronic Journal Of Social Sciences, 15(59), 1392-1402.

Yücel, E. K. (2017). Demografik Özelliklerin Satın Alma Karar Tarzları Üzerine Etkisi: Beyaz Eşya Ürünleri Üzerine Bir Uygulama. AKÜ İktisadi ve İdari Bilimler Fakültesi Dergisi, 19(2), 53-68. 